\title{
Pre - Proparathyroid Hormone Identified by Cell-Free Translation of Messenger RNA from Hyperplastic Human Parathyroid Tissue
}

\author{
Joel F. Habener, Byron Kemper, John T. Potts, Jr., and \\ Alexander Rich \\ From the Endocrine Unit and Department of Medicine, Massachusetts General \\ Hospital and Harvard Medical School, Boston, Massachusetts 02114, and the \\ Department of Biology, Massachusetts Institute of Technology, \\ Cambridge, Massachusetts 02139
}

\begin{abstract}
A в S T R A C T An 8-15S fraction of RNA isolated from hyperplastic human parathyroid tissue (primary chiefcell hyperplasia) and translated in a cell-free extract of wheat germ directs the synthesis of a protein that shares antigenic determinants and tryptic peptides with parathyroid hormone and its previously recognized immediate precursor, proparathyroid hormone. In addition, the protein contains tryptic peptides not found in proparathyroid hormone and migrates more slowly than does proparathyroid hormone on both urea-acid and urea-sodium dodecyl sulfate polyacrylamide gels, indicating that it is more acidic and larger than proparathyroid hormone. Sequential Edman degradation of the cell-free protein, radiolabeled with $\left[{ }^{35} \mathrm{~S}\right]$ methionine, for 25 cycles released $\left[{ }^{35} \mathrm{~S}\right]$ methionine at cycles $1,7,11$, and 14 , indicating that the $\mathrm{NH}_{2}$-terminal peptide sequence of the protein differs from that of both proparathyroid hormone and parathyroid hormone. We propose that this protein is an early biosynthetic precursor of human parathyroid hormone, pre-proparathyroid hormone, analogous to that identified recently by in vitro translation of bovine parathyroid mRNA.
\end{abstract}

\section{INTRODUCTION}

The principal molecular species of parathyroid hormone $(\mathrm{PTH})^{1}$ that has been isolated from parathyroid tissue

Dr. Habener is the recipient of a U. S. Public Health Service Career Development Award. Dr. Kemper is the recipient of a Fellowship from the Medical Foundation and Adams Trust (Boston).

Received for publication 17 September 1974 and in revised form 8 August 1975.

${ }^{1}$ Abbreviations used in this paper: CFP, cell-free protein or product; mRNA, messenger ribonucleic acid; Pre-ProPTH, preproparathyroid hormone; ProPTH, proparathyroid hormone; $\mathrm{PTH}$, parathyroid hormone; SDS, sodium consists of a single-chain polypeptide of 84 amino acids $(1,2)$. A larger biosynthetic precursor of $\mathrm{PTH}$ of at least 90 amino acids, proparathyroid hormone (ProPTH), or "calcemic fraction A" (3), has been observed in intact parathyroid cells of human (4-7), bovine (8$10)$, avian (11), and murine (12) origin.

Recently, the cell-free translation of RNA from bovine parathyroid glands has indicated the existence of a polypeptide even larger than ProPTH, which has been termed "pre-proparathyroid hormone" (Pre-ProPTH) (13). This evidence for a precursor of PTH larger than ProPTH has stimulated our interest in further delineating the initial product of translation of parathyroid messenger RNA (mRNA) and the function of PTH precursors in the control of PTH biosynthesis. We therefore felt it would be useful to examine a parathyroid tissue from a species other than the bovine for the existence of a larger precursor of PTH.

To identify directly the earliest precursor form of $\mathrm{PTH}$ and the initial product of the gene for $\mathrm{PTH}$, we have translated, in a heterologous cell-free system derived from wheat germ, the mRNA isolated from human parathyroid tissue obtained from a patient with primary chief-cell hyperplasia. The major product of synthesis is a parathyroid protein, similar to the cell-free product of the bovine mRNA (13) in that it is larger than ProPTH.

\section{METHODS}

Preparation of RNA. RNA was prepared from $5 \mathrm{~g}$ of fresh hyperplastic (chief-cell) parathyroid tissue by homogenization in $20 \mathrm{ml}$ of $0.01 \mathrm{M}$ Tris $\mathrm{HCl}, \mathrm{pH} \mathrm{7.4,0.5 \%}$

dodecyl sulfate; TCA, trichloroacetic acid; TSSE buffer, $0.01 \mathrm{M}$ Tris- $\mathrm{HCl}, \mathrm{pH} 7.4,0.5 \%$ sodium dodecyl sulfate, 0.1 $\mathrm{M} \mathrm{NaCl}$, and $1 \mathrm{mM}$ EDTA. 
sodium dodecyl sulfate (SDS), $0.1 \mathrm{M} \mathrm{NaCl}$, and $1 \mathrm{mM}$ EDTA (TSSE) buffer followed by repeated extractions in phenol-chloroform-isoamyl alcohol and sedimentation through a $5-20 \%$ sucrose gradient as described previously (13). RNA's sedimenting between 28 and $18 \mathrm{~S}$ (fraction A), 18 and $15 \mathrm{~S}$ (fraction $\mathrm{B}$ ), and 15 and $8 \mathrm{~S}$ (fraction $\mathrm{C}$ ) were collected separately and stored in water at $-20^{\circ} \mathrm{C}$.

Cell-free translation of $m R N A$. Approximately $10 \mu \mathrm{g}$ of RNA was translated in a cell-free system (final volume of $50 \mu 1)$ with an active extract of commercial wheat germ (Bar-Rev Mill, Tel Aviv, Israel) under the conditions described previously $(13,14)$. Reaction mixtures contained either $\left[{ }^{35} \mathrm{~S}\right]$ methionine $(320 \mathrm{Ci} / \mathrm{mmol}$, Amersham/Searle Corp., Arlington Heights, Ill.) or $\left[4,5-{ }^{3} \mathrm{H}\right]$ lysine $(40 \mathrm{Ci} /$ mmol, New England Nuclear, Boston, Mass.) and were incubated for up to $180 \mathrm{~min}$ at $23^{\circ} \mathrm{C}$. The incorporation of radioactive amino acid into protein during the incubation was assessed by precipitation of $1-\mu 1$ aliquots of the incubation mixture in $10 \%$ trichloroacetic acid (TCA) $(13,15)$.

Polyacrylamide gel electrophoresis. $10 \%$ polyacrylamide gels containing either $8 \mathrm{M}$ urea- $0.1 \mathrm{M}$ potassium acetate $(\mathrm{pH} 4.4)$ or $8 \mathrm{M}$ urea-0.1\% SDS, $0.2 \mathrm{M}$ phosphate $(\mathrm{pH}$ 7.0 ), were used to characterize the products of the cell-free synthesis $(8,15)$. 1-mm slices of the gels were counted in a toluene-based scintillator after swelling in a mixture of toluene-NCS solubilizer (Searle Analytic Inc., Des Plaines, IIl.)-water. Alternatively, the major cell-free product (CFP) was extracted after electrophoresis from 1-mm slices of urea-SDS polyacrylamide gels with $0.2 \mathrm{ml}$ of $0.5 \mathrm{M}$ sodium phosphate, $\mathrm{pH} 7.2,0.1 \%$ SDS, $1 \mathrm{mM}$ phenylmethylsulfonyl fluoride for tryptic digestion and for analysis on urea-acetate gels.

Immune precipitation. 5- $\mu 1$ aliquots of the cell-free incubate were pipetted into $200 \mu \mathrm{l}$ of phosphate with $2 \%$ bovine serum albumin ( $\mathrm{pH}$ 7.2). 50- $\mu 1$ aliquots of this solution were incubated at $4^{\circ} \mathrm{C}$ for $24 \mathrm{~h}$ in a final volume of $0.5 \mathrm{ml}$ containing $0.05 \mathrm{M}$ Veronal, $5 \%$ human plasma, $0.01 \%$ thimerosal, and either guinea pig antisera to bovine $\mathrm{PTH}$, containing antibodies that recognize antigenic determinants in both the $\mathrm{NH}_{2}$ - and $\mathrm{COOH}$-terminal sequences of PTH (16), or normal guinea pig serum $(1: 2,000)$ with and without addition of $2 \mu \mathrm{g}$ of bovine PTH. The incubation solutions were centrifuged at $2,000 \mathrm{~g}$ for $15 \mathrm{~min}, 50 \mu \mathrm{l}$ of rabbit anti-guinea pig globulin serum was added to the supernate, and the mixture was incubated for an additional $24 \mathrm{~h}$. The immune precipitates were analyzed by polyacrylamide gel electrophoresis $(8,15)$.

Radioimmunoassay. 50- $\mu 1$ aliquots of the cell-free incubation mixture taken at 0,1 , and $2 \mathrm{~h}$ were pipetted into a $0.3-\mathrm{ml}$ solution of $0.05 \mathrm{M}$ Veronal-2\% bovine serum albumin. 50 - and $100-\mu 1$ aliquots were assayed in a competitive-binding radioimmunoassay for $\mathrm{PTH}$ as described previously (17).

Preparation of radiolabeled PTH and ProPTH. Hyperplastic parathyroid tissue was incubated at $37^{\circ} \mathrm{C}$ in Earle's balanced salt solution supplemented with $5 \%$ fetal calf serum and all essential amino acids except lysine or methionine. $100 \mathrm{mg}$ of parathyroid tissue was preincubated in the medium at $37^{\circ} \mathrm{C}$ for $45 \mathrm{~min}$. $\left[\right.$ Methyl $\left.-{ }^{3} \mathrm{H}\right]$ methionine or $\left[{ }^{14} \mathrm{C}\right]$ lysine (New England Nuclear) was added, and the incubations were carried out for an additional $25 \mathrm{~min}$ for the isolation of ProPTH, and for $90 \mathrm{~min}$ for the isolation of PTH. The tissues were homogenized in a Dounce homogenizer in $8 \mathrm{M}$ urea- $0.2 \mathrm{~N} \mathrm{HCl}$, and ProPTH and PTH were isolated from the extracts by gel electrophoresis as described previously $(8,15)$.
Analyses of tryptic peptides of the CFP and ProPTH. Aliquots of the cell-free protein (CFP) labeled with $\left[{ }^{3} \mathrm{H}\right]-$ lysine and $\left[{ }^{35} \mathrm{~S}\right]$ methionine and ProPTH labeled with $\left[{ }^{14} \mathrm{C}\right]-$ lysine and $\left[{ }^{3} \mathrm{H}\right]$ methionine extracted from urea-SDS gels were mixed, respectively, in a ratio of ${ }^{3} \mathrm{H}$ to ${ }^{14} \mathrm{C}$ (or ${ }^{35} \mathrm{~S}$ ) of 4 to 1 (counts per $\mathrm{min}$ ). The combined extracts were lyophilized to dryness and redissolved in $0.2 \mathrm{ml}$ of $0.08 \mathrm{~N}$ ammonium hydroxide; $0.2 \mathrm{ml}$ of $8 \mathrm{M}$ urea was added. The solutions were passed over a column of Bio-Gel P-2 (BioRad Laboratories, Richmond, Calif.) in $0.15 \mathrm{~N}$ acetic acid, and the void-volume fraction was lyophilized, dissolved in $0.2 \mathrm{ml}$ of performic acid (prepared by incubating formic acid and $30 \%$ hydrogen peroxide $19: 1$ [vol/vol] at $25^{\circ} \mathrm{C}$ for $2 \mathrm{~h}$ ), and incubated at $25^{\circ} \mathrm{C}$ for $2 \mathrm{~h}$. The performic acid was removed by reducing the volume to $1 / 5$ under vacuum, adding $1 \mathrm{ml}$ water, lyophilizing to dryness, redissolving in water, and lyophilizing again to dryness. The final dry powders were dissolved in $0.05 \mathrm{ml}$ of $0.2 \mathrm{M}$ ammonium bicarbonate buffer, $\mathrm{pH} 8.5$, trypsinized, and analyzed by paper electrophoresis as described previously $(8$, $15,18)$.

Partial sequence analysis of $\left.{ }^{35} S\right]$ methionine-labeled $C F P$. CFP labeled with $\left[{ }^{35} \mathrm{~S}\right]$ methionine (an aliquot of the major protein characterized in the study shown in Fig. 2) was subjected to 25 cycles of sequential Edman degradation with a Beckman 890 protein sequenator (Beckman Instruments, Inc., Spinco Div., Palo Alto, Calif.). The radioactive amino acids released during the degradation were analyzed by methods described previously (6).

\section{RESULTS}

Protein synthesis directed by parathyroid $R N A$. All three fractions of RNA from the sucrose gradient were active in directing incorporation of amino acids into protein, but fraction $\mathrm{C}$ was significantly more active than the other fractions (Fig. 1). The RNA in this fraction stimulated incorporation of $\left[{ }^{35} \mathrm{~S}\right]$ methionine 30 fold over control (without added RNA). Radioimmunoassay of aliquots of the incubation with RNA from frac-

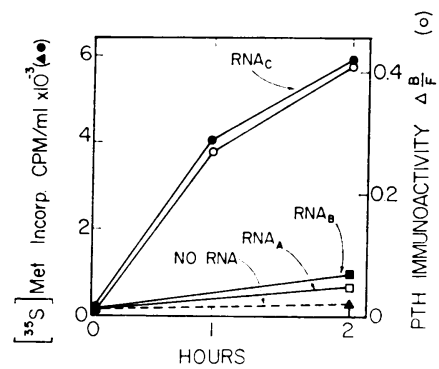

FIGURE 1 Stimulation of protein synthesis in extracts of wheat germ by parathyroid RNA. Conditions of cell-free synthesis are described in Methods. Data shown are: $(a)$ incorporation of $\left[{ }^{35} \mathrm{~S}\right]$ methionine into total TCA-insoluble protein (50- $\mu$ l incubation volume) in response to approximately $10 \mu \mathrm{g}$ of parathyroid RNA from fractions A ( $\square)$, $B(\boldsymbol{D})$, and $C(\bullet)$ isolated by sucrose gradient sedimentation; $(b)$ fall in bound-to-free ratio of ${ }^{125}$ I-labeled bovine $\mathrm{PTH}(\Delta \mathrm{B} / \mathrm{F})$ produced by $15 \mu \mathrm{l}$ of the incubation mixtures in a competitive-binding radioimmunoassay for $\mathrm{PTH}$ (O). 


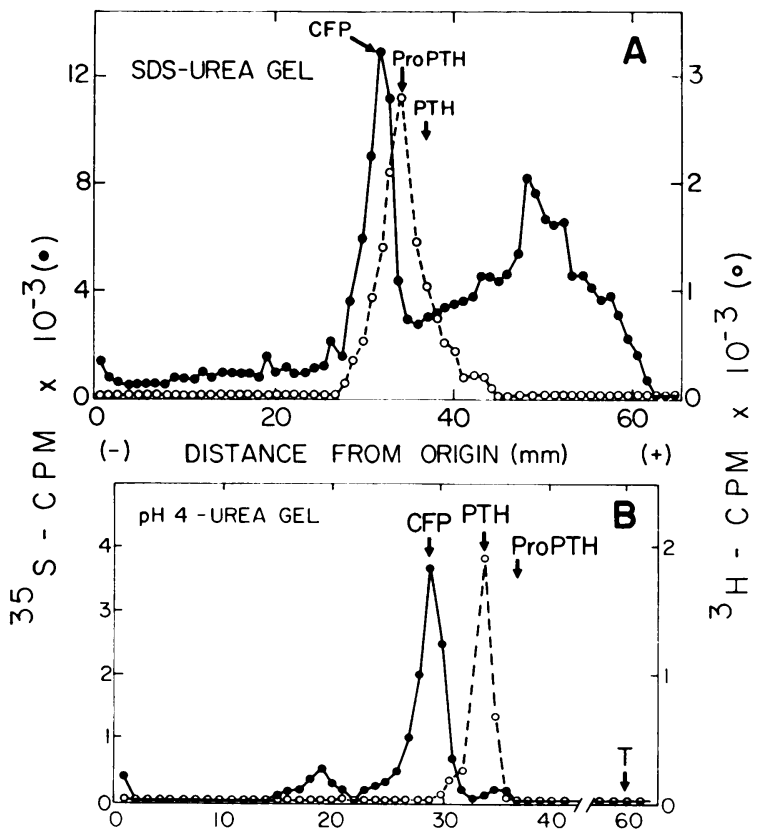

(t) DISTANCE FROM ORIGIN (mm) (-)

FIGURE 2 Polyacrylamide gel electrophoresis profiles. Upper panel (A) shows analysis by SDS-acrylamide gel of the $\left[{ }^{35} \mathrm{~S}\right]$ methionine-labeled $\mathrm{CFP}$ of protein synthesis directed by RNA fraction $C$ from sucrose gradient sedimentation (Fig. 1) (๑). Lower panel (B) shows analysis by urea-acetate acrylamide gel $(\mathrm{pH} 4)$ of the CFP isolated from the SDS-acrylamide gel shown in upper panel. Details of the electrophoresis are described in Methods. $\left[{ }^{3} \mathrm{H}\right]$ ProPTH and $\left[{ }^{3} \mathrm{H}\right] \mathrm{PTH}$ (see Methods) were added as markers (O).

tion $\mathrm{C}$ showed a parallel increase in immunoreactivity of PTH (Fig. 1). A rough estimate of the amount of PTHlike material synthesized indicates the production of approximately 1-2 $\mathrm{ng}$ of $\mathrm{PTH}$ in a $50-\mu 1$ incubation mixture.

Polyacrylamide gel electrophoresis of the products of cell-free synthesis. About $30 \%$ of the radioactive protein synthesized in a wheat germ extract containing RNA from fraction $C$ migrated as a single discrete peak (CFP) on SDS-acrylamide gels with a mobility corresponding to a molecular weight of about 14,000 daltons, compared with 10,200 daltons for ProPTH (Fig. 2A). The products synthesized in response to RNA in fractions $\mathrm{A}$ and $\mathrm{B}$, the region of the sucrose gradient where mRNA coding for larger proteins should appear, were proteins smaller than ProPTH (not shown). CFP isolated from a SDS gel was reanalyzed by electrophoresis on a polyacrylamide gel in $8 \mathrm{M}$ urea at $\mathrm{pH} 4.4$ (Fig. 2B). The results indicate that $\mathrm{CFP}$ is one major protein that migrates more slowly than either ProPTH or PTH. At this $\mathrm{pH}$, ProPTH migrates more rapidly than $\mathrm{PTH}$, even though it is larger than PTH owing to its greater

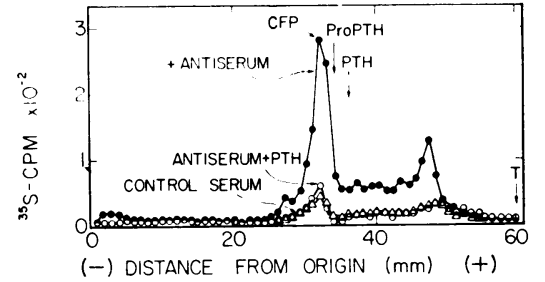

Figure 3 SDS-acrylamide gel analysis of immunoprecipitates of $\left[{ }^{35} \mathrm{~S}\right]$ methionine-labeled CFP. Immunoprecipitate fractions from incubation mixture after treatment with antiserum to PTH $(\bullet)$, antiserum to PTH and $2 \mu \mathrm{g}$ of PTH $(O)$, nonimmune control serum $(\Delta)$. The ordinate scale denotes the radioactivity in the immune precipitate fractions. The three acrylamide gel patterns are coplotted in the figure. CFP, major cell-free product. Arrows mark the electrophoretic positions of ProPTH, PTH, and the bromphenol blue dye ( $\mathrm{T})$.

positive charge $(6,7,10)$. This observation indicates that the extra peptide sequence unique to CFP probably contains a large complement of acidic or neutral amino acids, or both.

Immune precipitation studies. Structural similarity between the CFP and ProPTH was demonstrated by finding that an antiserum containing antibodies to $\mathrm{PTH}$ specifically bound the protein (Fig. 3). Moreover, the antiserum also bound a substantial fraction of the more rapidly migrating peptides that probably represent incompleted chains of the major protein $(14,19)$. Binding of CFP was inhibited by addition of excess PTH to the incubation, and little binding was observed when control, nonimmune serum was used.

Tryptic peptide analyses. A further indication that the major protein from the cell-free synthesis contains within its structure the sequence of ProPTH was obtained through paper electrophoresis of the peptides formed by tryptic digestions of solutions containing $\left[{ }^{3} \mathrm{H}\right]$ lysine-labeled $\mathrm{CFP}$ and $\left[{ }^{14} \mathrm{C}\right]$ lysine-labeled ProPTH and $\left[{ }^{35} \mathrm{~S}\right]$ methionine-labeled $\mathrm{CFP}$ and $\left[{ }^{3} \mathrm{H}\right]$ methioninelabeled ProPTH (Fig. 4). Overall, the mobilities of the peptides derived from the CFP and from ProPTH correspond well. In particular, there is coincident migration of the peptides corresponding to the ProPTH-specific hexapeptide sequence -6 to +1 (8) (see VII and $\mathrm{X}$, Fig. 4). Additional peptides in the CFP and not in ProPTH appear in the peptides migrating between 0 and $20 \mathrm{~cm}^{2}$

Sequential Edman degradation of $\left[{ }^{35} S\right]$ methionine-labeled CFP. $\left[{ }^{35} \mathrm{~S}\right]$ Methionine was released at cycles 1 ,

\footnotetext{
${ }^{2}$ A previous report (13) indicating that the analogous CFP obtained by translation of bovine mRNA contained only two $\left[{ }^{35} \mathrm{~S}\right]$ methionine-labeled tryptic peptides was in error. Additional methionine-containing peptides that eluded detection because of poor solubility have been detected subsequently (studies in progress).
} 
7,11 , and 14 during a 25-cycle sequential Edman degradation of the $\mathrm{NH}_{2}$-terminal sequence of $\left[{ }^{35} \mathrm{~S}\right]$ methioninelabeled CFP. This observation indicates that the $\mathrm{NH}_{2}-$ terminal sequence of the CFP differs from that of Pro$\mathrm{PTH}$ (or PTH) $(6,20)$ and that at least part of the additional peptide sequence uniquely contained in the CFP (Fig. 4) is at the $\mathrm{NH}_{2}$-terminus of the polypeptide. $^{3}$

\section{DISCUSSION}

These studies show that an 8-15S RNA fraction from human parathyroid tissue contains a messenger RNA that directs the synthesis of a PTH protein in a cellfree system. The CFP shares antigenic determinants in common with PTH and lysine- and methionine-containing tryptic peptides in common with ProPTH and is both more acidic and larger than ProPTH, as determined by gel electrophoresis. The results of the tryptic peptide analysis and the sequential Edman degradation indicate that the protein consists of ProPTH with at least an additional peptide sequence at the $\mathrm{NH}_{2}$ terminus of the human ProPTH polypeptide chain. These findings with the parathyroid RNA of human origin agree with

\footnotetext{
${ }^{3}$ Because human PTH contains only two methionines (positions 8 and 18), sequential degradation of ProPTH would have released $\left[{ }^{35} \mathrm{~S}\right]$ methionine at cycles 14 and 24 .
}

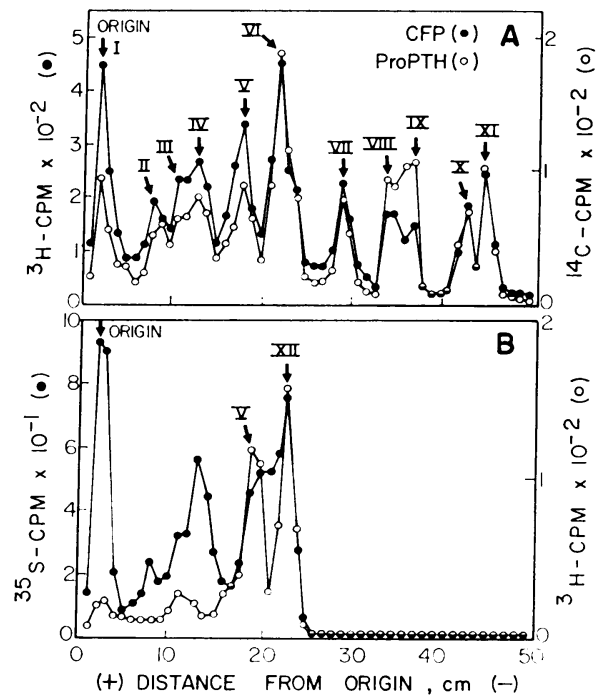

Figure 4 Paper electrophoresis of the $\left[{ }^{3} \mathrm{H}\right]$ lysine-labeled (A) and $\left[{ }^{35} \mathrm{~S}\right]$ methionine-labeled (B) tryptic peptides of the CFP. $\left[{ }^{14} \mathrm{C}\right]$ Lysine-labeled (A) and $\left[{ }^{3} \mathrm{H}\right]$ methioninelabeled (B) ProPTH were coanalyzed with the CFP isolated from SDS-acrylamide gels as described in Methods. Previous studies of human $(32)$ and bovine $(18,33)$ PTH and of bovine ProPTH $(17,24)$ suggest that the peaks of radioactivity contain the following tryptic peptide sequences: $\mathrm{V}, 1$ to 13 ; VI, 55 to 65 and 81 to 84 ; VII, -5 to -3 ; IX, lysine; X, -2 to -1 ; XI, dilysine; XII, 14 to 20 . those obtained with bovine RNA (13) and further substantiate our postulation that the CFP, Pre-ProPTH, is a biosynthetic precursor of human ProPTH (13).

The alternative explanation for our findings, that the CFP is an artifactual product of the in vitro synthesis, now seems to us to be remote, inasmuch as isolation and translation of mRNA from the two different parathyroid sources give similar products. In addition, translation of bovine parathyroid RNA in a second cell-free system (Krebs-II ascites cells) gives a product identical to the CFP from wheat germ." Moreover, translations in extracts of wheat germ done recently of RNA's from other endocrine tissues have yielded larger, "prehormone" forms of insulin (21), growth hormone (22), and placental lactogen (23).

A more extensive characterization of the bovine PreProPTH than was initially described in our earlier publication (13) indicates that it not only contains 25 additional amino acids at the $\mathrm{N}$ terminus of ProPTH, but that both initiation and termination of the synthesis of the Pre-ProPTH polypeptide in the wheat germ extract do occur accurately (24).

It has been difficult to identify a protein corresponding to the CFP in studies of PTH synthesis in vitro in preparations of intact parathyroid cells (24). Thus, in vivo Pre-ProPTH must be cleaved to ProPTH very rapidly after synthesis ; the $\mathrm{NH}_{2}$-terminal peptide ("pre"peptide) might even be removed before the $\mathrm{COOH}$ terminal sequence of the ProPTH is completely synthesized. In the wheat germ extracts, the specific enzymic activity responsible for the cleavage appears to be absent.

The concept of extremely rapid proteolytic cleavages of proteins during the assembly of amino acids on the polyribosome has been introduced previously $(25,26)$. Very early, transient biosynthetic precursors of immunoglobulin light chain $(25,27)$, polio virus (26), and encephalomyocarditis-virus proteins (28) have been identified. It has been proposed that the $\mathrm{NH}_{2}$-terminal region of the precursor peptide may function in the transport of the protein through the reticular membrane into the cisternal space as an initial step in the subsequent cellular transport and eventual export of the protein from the cell (25).

The prior identification of ProPTH and the present identification of a possible earlier precursor, Pre-Pro$\mathrm{PTH}$, raise the possibility that under specific circumstances, such as prolonged glandular stimulation or neoplastic transformation, one or both of these larger forms of PTH may accumulate in the gland or be secreted from the gland into the circulation in vivo. Wong and Lindall (29) and Benson et al. (30) recently reported findings that are consistent with the production and secretion of immunoreactive molecular forms larger than PTH.

\footnotetext{
${ }^{4}$ To be published.
} 
Attempts thus far to detect ProPTH in the blood by specific radioimmunoassay have been unsuccessful, perhaps partly because of rapid conversion of ProPTH to PTH by trypsin-like activity in the blood (31). The results of the studies in progress, however, suggest that Pre-ProPTH may be unusually resistant to proteolytic cleavage by enzymes; homogenates of parathyroid tissue that readily convert ProPTH to PTH do not specifically convert Pre-ProPTH to ProPTH or to PTH. Thus, if Pre-ProPTH is secreted into the circulation under conditions of abnormal glandular activity, it may circulate in amounts sufficient to be detectable once a suitable radioimmunoassay is available.

\section{ACKNOWLEDGMENTS}

We thank Dr. Bryan Roberts and Mr. Richard Mulligan for helpful assistance and Dr. C. A. Wang for providing the parathyroid tissue.

This work was supported by grants from the National Institutes of Health, the National Science Foundation, and the J. A. Hartford Foundation, Inc.

\section{REFERENCES}

1. Brewer, H. B., Jr., and R. Ronan. 1970. Bovine parathyroid hormone: amino acid sequence. Proc. Natl. Acad. Sci. U.S. A. 67: 1862-1869.

2. Niall, H. D., H. Keutmann, R. Sauer, M. Hogan, B. Dawson, G. Aurbach, and J. Potts, Jr. 1970. The amino acid sequence of bovine parathyroid hormone I. HoppeSeyler's Z. Physiol. Chem. 351: 1586-1588.

3. Cohn, D. V., R. R. MacGregor, L. L. H. Chu, and J. W. Hamilton. 1972. Studies on the biosynthesis in vitro of parathyroid hormone and other calcemic polypeptides of the parathyroid gland. In Calcium, Parathyroid Hormone and the Calcitonins: Proceedings of the Fourth Parathyroid Conference. R. V. Talmage and P. L. Munson, editors. Excerpta Medica, Amsterdam. 173-182.

4. Habener, J. F., B. Kemper, J. T. Potts, Jr., and A. Rich. 1972. Proparathyroid hormone: biosynthesis by human parathyroid adenomas. Science (Wash. D. C.). 178: 630-633.

5. Chu, L. L. H., R. R. MacGregor, P. I. Liu, J. W. Hamilton, and D. V. Cohn. 1973. Biosynthesis of proparathyroid hormone and parathyroid hormone by human parathyroid glands. J. Clin. Invest. 52: 3089-3094.

6. Jacobs, J. W., B. Kemper, H. D. Niall, J. F. Habener, and J. T. Potts, Jr. 1974. Structural analysis of human proparathyroid hormone by a new microsequencing approach. Nature (Lond.). 249: 155-157.

7. Huang, W-Y., L. L. H. Chu, J. W. Hamilton, D. H. McGregor, and D. V. Cohn. 1975. The $\mathrm{NH}_{2}$-terminal amino acid sequence of human proparathyroid hormone by radioisotope microanalysis. Arch. Biochem. Biophys. 166: $67-71$.

8. Kemper, B., J. F. Habener, J. T. Potts, Jr., and A. Rich. 1972. Proparathyroid hormone: identification of a biosynthetic precursor to parathyroid hormone. Proc. Natl. Acad. Sci. U. S. A. 69: 643-647.

9. Cohn, D. V., R. R. MacGregor, L. L. H. Chu, J. R. Kimmel, and J. W. Hamilton. 1972. Calcemic fraction-A : biosynthetic peptide of precursor of parathyroid hormone. Proc. Natl. Acad. Sci. U. S. A. 69: 1521-1525.
10. Hamilton, J. W., H. D. Niall, J. W. Jacobs, H. T. Keutmann, J. T. Potts, Jr., and D. V. Cohn. 1974. The Nterminal amino acid sequence of bovine proparathyroid hormone. Proc. Natl. Acad. Sci. U. S. A. 71: 653-656.

11. MacGregor, R. R., L. L. H. Chu, J. W. Hamilton, and D. V. Cohn. 1973. Partial purification of parathyroid hormone from chicken parathyroid glands. Endocrinology. 92: $1312-1317$

12. Chu, L. L. H., R. R. MacGregor, C. S. Anast, J. W. Hamilton, and D. V. Cohn. 1973. Studies on the biosynthesis of rat parathyroid hormone and proparathyroid hormone: adaptation of the parathyroid gland to dietary restriction of calcium. Endocrinology. 93: 915-924.

13. Kemper, B., J. F. Habener, R. C. Mulligan, J. T. Potts, Jr., and A. Rich. 1974. Pre-proparathyroid hormone: a direct translation product of parathyroid messenger RNA. Proc. Natl. Acad. Sci. U. S. A. 71: 3731-3735.

14. Roberts, B. E., and B. M. Paterson. 1973. Efficient translation of tobacco mosaic virus RNA and rabbit globin 9S RNA in a cell-free system from commercial wheat germ. Proc. Natl. Acad. Sci. U. S. A. 70: 2330-2334.

15. Habener, J. F., and J. T. Potts, Jr. 1975. Technique for the identification of a biosynthetic precursor of parathyroid hormone. Methods Enzymol. 37 : 345-360.

16. Segre, G. V., J. F. Habener, D. Powell, G. W. Tregear, and J. T. Potts, Jr. 1972. Parathyroid hormone in human plasma. Immunochemical characterization and biological implications. J. Clin. Invest. 51: 3163-3172.

17. Habener, J. F., G. P. Mayer, D. Powell, T. M. Murray, F. R. Singer, and J. T. Potts, Jr. 1973. Dextran-charcoal and dioxane phase separation methods in the radioimmunoassays for parathyroid hormone and calcitonin. Clin. Chim. Acta. 45 : 225-233.

18. Habener, J. F., B. Kemper, J. T. Potts, Jr., and A. Rich. 1973. Bovine proparathyroid hormone: structural analysis of radioactive peptides formed by limited cleavage. Endocrinology. 92: 219-226.

19. Roberts, B. E., M. B. Matthews, and C. J. Bruton. 1973. Tobacco mosaic virus RNA directs the synthesis of a coat protein peptide in a cell-free system from wheat. J. Mol. Biol. 80: 733-742.

20. Niall, H. D., R. T. Sauer, J. W. Jacobs, H. T. Keutmann, G. V. Segre, J. L. H. O'Riordan, G. D. Aurbach, and J. T. Potts, Jr. 1974. The amino-acid sequence of the amino-terminal 37 residues of human parathyroid hormone. Proc. Natl. Acad. Sci. U. S. A. 71: 384-388.

21. Permutt, M. A. In Proceedings of CIBA Symposium on the Formation and Release of Peptide Hormones. July, 1975. In press.

22. Bancroft, F. C., and P. M. Sussman. 1975. Progrowth hormone: the product of the cell-free translation of growth hormone messenger RNA. In Proceedings of the 57th Meeting of the Endocrine Society, New York. 111. (Abstr.)

23. Boime, I., S. Boguslawski, and J. Caine. 1975. The translation of a human placental lactogen mRNA fraction in heterologous cell-free systems: the synthesis of a possible precursor. Biochem. Biophys. Res. Commun. 62: 103-109.

24. Habener, J. F., B. Kemper, A. Rich, and J. T. Potts, Jr. 1975. Pre-proparathyroid hormone: partial sequence determination of a 115-amino-acid polypeptide precursor of parathyroid hormone. Clin. Res. 23: 321A.

25. Milstein, C., G. G. Brownlee, T. M. Harrison, and M. B. Matthews. 1972. A possible precursor of immunoglobulin light chains. Nat. New Biol. 239: 117-120. 
26. Jacobson, M. F., J. Asso, and D. Baltimore. 1970. Further evidence on the formation of poliovirus proteins. J. Mol. Biol. 49: 657-669.

27. Scheckter, I. 1973. Biologically and chemically pure mRNA coding for a mouse immunoglobulin L-chain prepared with the aid of antibodies and immobilized oligothymidine. Proc. Natl. Acad. Sci. U. S. A. 70: 2256-2260.

28. Boime, I., and P. Leder. 1972. Protein synthesis directed by encephalomyocarditis virus mRNA. III. Discrete polypeptides translated from a monocistronic messenger in vitro. Arch. Biochem. Biophys. 153: 706-713.

29. Wong, E. T., and A. W. Lindall. 1973. Preliminary evidence for a microsomal precursor to human parathyroid hormone. Proc. Natl. Acad. Sci. U. S. A. 70: 2291-2294.

30. Benson, R. C. Jr., B. L. Riggs, B. M. Pickard, and C. D. Arnaud. 1974. Immunoreactive forms of circu- lating parathyroid hormone in primary and ectopic hyperparathyroidism. J. Clin. Invest. 54: 175-181.

31. Habener, J. F., G. W. Tregear, T. S. Stevens, P. C. Dee, and J. T. Potts, Jr. 1974. Radioimmunoassay for proparathyroid hormone. Endocrine Res. Commun. 1: $1-17$.

32. Keutmann, H. T., H. D. Niall, J. Jacobs, P. M. Barling, C. N. Hendy, J. L. H. O'Riordan, and J. T. Potts, Jr. A reinvestigation of the amino-terminal sequence of human parathyroid hormone (residues 1-34) and analysis of the sequence of residues 44-69. In Proceedings of the Fifth Parathyroid Conference, Oxford, 1974. R. V. Talmagr editor. Excerpta Medica, Amsterdam. In press.

33. Potts, J. T., Jr., G. D. Aurbach, L. M. Sherwood, and A. Sandoval. 1965. Structural basis of biological and immunological activity of parathyroid hormone. Proc. Natl. Acad. Sci. U. S. A. 54: 1743-1751. 